\title{
Photoperiod and feeding behavior of the Antarctic fish Notothenia rossii (Perciformes: Nototheniidae) and functional morphology of chemical and visual sensory structures used in foraging
}

\author{
Lucélia Donatti ${ }^{\text {; }}$ Tânia Zaleski ${ }^{2}$; Patrícia Calil ${ }^{3}$ \& Edith Fanta ${ }^{1,4}$ \\ ${ }^{1}$ Departamento de Biologia Celular, Universidade Federal do Paraná, Caixa Postal 19031, 81531-970 Curitiba, Paraná, \\ Brasil. E-mail: donatti@ufpr.br \\ 2 Programa de Pós-graduação em Zoologia, Departamento de Zoologia, Universidade Federal do Paraná. \\ Caixa Postal 10920, 81531-980 Curitiba, Brasil. \\ ${ }^{3}$ Centro Universitário Campos de Andrade. Rua Marumby 283, 81220-090 Curitiba, Paraná, Brasil. \\ ${ }^{4}$ In memoriam.
}

\begin{abstract}
The influence of photoperiod on the ability of Notothenia rossii Richardson, 1844 to detect prey was studied experimentally. In 12L/12D there was the highest number of individuals stimulated visually and chemically while in 24D chemical perception was the same as that observed in $12 \mathrm{~L} / 12 \mathrm{D}$, the latter being lower than in 24L. The ultrastructure of chemo- and photo-sensory structures, involved in the detection of food, was studied. The photoreceptor cells of the retina are single and double cones, and rods. Taste buds were concentrated in the central part of upper and lower lips. Their shape is even, but the size is variable. The olfactory rosette has a sensory and a non-sensory epithelium, being rich in different mucosubstances. The conclusion was that in different photoperiods there is a difference in the response to visual and chemical stimulation for prey detection and that all sensory systems are more stimulated in periods of more luminosity, mainly when there is an alternation between light and dark periods. Sensory organs are complex when compared to some other Antarctic fish such as Gobionotothen gibberifrons Lönnberg, 1905 and Ophthalmolycus amberensis Tomo, Marshoff \& Torno, 1977 but similar to those of $N$. coriiceps Rchardson, 1844.
\end{abstract}

KEY WORDS. Chemoreception; microscopy; photoreception.

RESUMO. Comportamento alimentar do peixe antártico Notothenia rossii (Perciformes: Nototheniidae) em diferentes fotoperíodos e a morfologia funcional das estruturas quimio-foto sensoriais usadas na detecção do alimento. A capacidade de Notothenia rossii Richardson, 1844 detectar presas in diferentes fotoperíodos $(24 \mathrm{~L}$, 24D e 12L/12D) foi estudada em tanques experimentais. Em 12L/12D houve um maior número de indivíduos estimulados visual e quimicamente enquanto que em $24 \mathrm{D}$ a percepção química foi a mesma que a observada em 12L/12D, sendo este ultimo inferior a 24L. A morfologia das estruturas quimio-foto sensoriais, envolvidas na detecção do alimento, foi estudada. As células fotorreceptoras da retina são os cones simples e duplos e os bastonetes. Os botões concentraram-se na região central dos lábios superior e inferior. Seu formato é constante, mas o tamanho é variável. A rosseta olfatória possui um epitélio sensorial e não sensorial rico mucosubstâncias de natureza diversa. Podemos concluir que em diferentes fotoperíodos existe uma diferença de resposta na estimulação visual e química para a detecção de persas e todo o sistema sensorial são mais estimulados em períodos de maior luminosidade, principalmente quando existe uma alternância entre períodos de luz e escuro. Os órgãos sensoriais são complexos quando comparados com outros peixes antárticos como Gobionotothen gibberifrons Lönnberg, 1905 e Ophthalmolycus amberensis Tomo, Marshoff \& Torno, 1977) mas similar a Notothenia coriiceps Richardson, 1844.

PALAVRAS-CHAVE. Fotorrecepção; microscopia; quimiorrecepção.

Feeding behaviors in many species of Antarctic fish are strongly influenced by photoperiod and light conditions in the Antarctic (Barrera Oro \& Casaux 1990, Fanta et al. 1994, DonatTi $\&$ FANTA 2002). These different feeding strategies are also re- lated to adaptations of the visual and chemical sensory systems (Meyer \& Fanta 1998, Fanta et al. 1994, 1999, 2001, DonatTi $\&$ FANTA 2001, 2002). Through chemo and photoreception, these fish may recognize habitat features and presence of prey, preda- 
tors and conspecifics (HaRa 1971, 1986, Macdonald \& MontGOMERY 1991). However, due to the seasonally limited light conditions in the Antarctic, a tendency towards dominance of mechanoreceptors exists in some species, such as nototheniids (Montgomery \& Macdonald 1987, Montgomery \& Coombs 1992). Also, chemoreception (including smell, taste and a general chemical sense, HARA 1971) is complex and in water, all chemosensory receptors may be stimulated by all chemicals in the water (Valentincic \& Caprio 1994). Structural analyses of the retina in Antarctic nototheniids show no specific retinal adaptations for low-luminosity vision for species of shallow waters (Meyer-Rochow \& Klyne 1982, Eastmann 1988).

Commercial fishing in the Antarctic has increased the importance of understanding the biology of Antarctic fish, such as N. rossii Richardson, 1844 (TARVerdyieva \& Pinskaya 1972). The most economically important species are in Nototheniidae and Chaenichthydae (TARgETT 1981), which have long lives, low fecundity and slow growth compared to other cold water species (Mckenna \& Saila 1991).

Despite the Convention for the Conservation of Antarctic Marine Living Resources, and of the Protocol to the Antarctic Treaty, and their conservation measures, fishing levels have increased and are now intense for some Antarctic species (SKÓRA \& Sosinski 1983, Policansky 1994). Notothenia rossii is an important species for its flesh and eggs. In the early 1970s stocks were depleted, conservation measures were adopted (FISHER \& HUREAU 1985) and today commercial fishing is prohibited until the stocks recover (CCAMLR 2007).

Little is known of the feeding ecology of $N$. rossii. Feeding habits and preferred habitats change ontogenetically (HUREAU 1970, TARVERDyieva 1972). It is a voracious predator (GoN \& HeEmstra 1990). In Admiralty Bay, while amphipods are dominant in the diet year-round, $N$. rossii favored salps during summer and polychaetes during the winter (LinkowsKi et al. 1983). In Potter Bay, gammarid amphipods were its main prey, yet other species were common in its diet (CASAUX et al. 1990). In addition to amphipods, this fish also favors krill (FANTA et al. 2001).

In this context, we compared the ability of Notothenia rossii to detect prey in different photoperiods by both visual and chemical means. Also, we examined the structure of the eyes (retina) and those of chemoreception (olfactory rosette and labial taste buds). We interpret the structure of the sensory organs within the context of this species' foraging ecology to better understand feeding behavior

\section{MATERIAL AND METHODS}

Notothenia rossii $(\mathrm{n}=24)$ (standard length $36.3 \pm 1.0 \mathrm{~cm}$, mean \pm S.D.) were collected in Admiralty Bay $\left(62^{\circ} 09^{\prime} \mathrm{S}, 58^{\circ} 26^{\prime} \mathrm{W}\right)$, King George Island, South Shetland Islands by trammel net, line and hook. At the Comandante Ferraz Brazilian Antarctic Station, fish were acclimated in tanks under controlled environmental conditions: temperature $0.5^{\circ} \mathrm{C} \pm 0.5$ (mean \pm S.D.), $\mathrm{pH}$ $7.0 \pm 0.5$ and salinity $36.0 \% 0 \pm 0.5$. Acclimation and tests were conducted under two photoperiod treatments: $12 \mathrm{~h}$ light, $12 \mathrm{~h}$ dark (12L/12D), and $24 \mathrm{~h}$ light (24L) and $24 \mathrm{~h}$ dark (24D). Light was provided by a daylight lamp with a gray translucent filter that reduced light intensity at the bottom of the tanks to 10-15 lux. A soft red lamp and an intensity of one lux at the bottom of the tanks simulated darkness following DonatTI \& FANTA (1999, 2002).

Two fish in each $500 \mathrm{~L}$ aquarium were used to test visual or chemical stimulation. To test visual perception to detect prey, a transparent vessel filled with water was placed in a corner of the tank, with no communication of water between the two (to eliminate the possibility of chemical perception). An $\sim 6.0$ $\mathrm{cm}$ piece of fish (1/3 the length of the predator, FanTA \& Meyer 1998) was shaken within the vessel to visually stimulate the predator. The time interval from the immersion of the fish into the vessel until the moment that the predator clearly responded was measured. To test chemical stimulation, fish extract was delivered to the aquarium through a hose. The time interval from delivery to the response by the predator was measured. Following FANTA et al. $(1999,2001)$ and DonatTI \& FANTA (2002) a 10 min maximum interval was used. Four treatments were used: 1) during light period of $12 \mathrm{~h}$ light, $12 \mathrm{~h}$ dark (12L/12D), 2) during dark period of $12 \mathrm{~L} / 12 \mathrm{D}, 3) 24 \mathrm{~L}$, and 4) $24 \mathrm{D}$. Each treatment had 15 replicates for visual and chemical stimulation. Fish were not fed for 24 hours prior to each test.

Four variables were used in analyses. 1) The number of individuals that responded in any recognizable way to the stimulus, 2) the time interval until response, 3) the number of times each fish physically attacked the vessel (in the visual test) and 4) the number times each individual attacked the hose (in the chemical test). Analysis of variance was used to compare the photoperiod treatments for each of these four variables. Significance was considered when $p<0.05$. (ZAR 1984).

Retinas, olfactory rosettes, upper and lower lips of 20 fish were removed after decerebration. For light microscopy (LM), samples were fixed in Alfac (16 hours), dehydrated in a graded alcohol series, cleared in xylene and embedded in Paraplast Plus $^{\circledast}$. Slides were stained with Haematoxylin and Eosin (H.E.) (Clark 1981) for general morphology and Alcian Blue pH 2.5 and $\mathrm{pH}$ 1.0, Periodic Acid Schiff (PAS) and Alcian Blue pH 2.5/ PAS to identify mucous secreting cells (Culuing et al. 1985).

For transmission electron microscopy (TEM), samples were fixed in Karnowski (4 hours), washed in cacodylate buffer $0.2 \mathrm{M}$ (pH 7.2) and post-fixed in $2 \%$ osmium tetroxyde in cacodylate buffer $0.2 \mathrm{M}(\mathrm{pH}$ 7.2) for 1 hour. Material was contrasted in blocks with $2 \%$ aqueous uranyle acetate for 2 hours and embedded in Epon 812 (LuFT 1961). Ultra-fine sections were contrasted in $2 \%$ aqueous uranyle acetate solution (WATSON 1958) and plumbous nitrate (REYNolds 1963). Analysis was under electron microscope (JEOL-JEM 1200 EX II - Electron Microscopy Centre - Federal University of Paraná (CME-UFPR)).

For scanning electron microscopy (SEM), samples were fixed in Karnovsky (4 hours) and washed in cacodylate buffer 
$0.2 \mathrm{M}$ (pH 7.2). The critical point was obtained with $\mathrm{CO}_{2}$ in a Balzers CPD-010 and coated with gold in a Balzers SCD-030. Microphotographs were obtained in a SEM (JEOL-JSM 6360 LV) (CME-UFPR).

\section{RESULTS}

\section{Number of fish stimulated}

Fish responded to both, visual and to chemical stimulus, at all photoperiod treatments. However, treatments were similar in the number of fish that responded to the stimulus in the time interval for both visual and chemical tests (all $\mathrm{p}>0.05$ ). In $24 \mathrm{~L}$, somewhat fewer fish responded visually $(1.33 \pm 0.51$, mean \pm S.D.) or chemically $(1.44 \pm 0.52)$. In $12 \mathrm{~L} / 12 \mathrm{D}$, the number of individuals stimulated was the same in both the chemical and visual tests $(1.00 \pm 0.00)$. In $24 \mathrm{D}$, fewer fish responded to visual simulation $(0.66 \pm 0.57)$, but chemical perception was the same as that observed in $12 \mathrm{~L} / 12 \mathrm{D}(1.00 \pm 0.00)$.

\section{Time to response}

The time to response was shorter in the photoperiod 12L/ $12 \mathrm{D}$ treatment $(51.33 \mathrm{~s} \pm 44.97)$ than in photoperiod $24 \mathrm{~L}$ (216.16s \pm 224.50$)$ and $24 \mathrm{D}(319.33 \mathrm{~s} \pm 69.06)$. Response time was also shorter for chemical stimulation in the photoperiod $12 \mathrm{~L} / 12 \mathrm{D}(240.00 \mathrm{~s} \pm 214.41), 24 \mathrm{~L}(273.66 \mathrm{~s} \pm 112.48)$ and $24 \mathrm{D}$ (273.83s \pm 86.94 , mean + S.D.). Clearly the fish responded more rapidly to chemical rather than visual stimuli, yet photoperiod had no influence on response time in either visual $\left(\mathrm{F}_{29}=1.87\right.$, $\mathrm{p}=0.20)$ or chemical $\left(\mathrm{F}_{2.15}=0.9, \mathrm{p}=0.91\right)$ tests.

\section{Number of attacks on the prey}

In the visual test, the number of attacks was greater in the $12 \mathrm{~L} / 12 \mathrm{D}$ treatment $(8.66 \pm 6.02)$ than either $24 \mathrm{~L}(2.50 \pm 2.73$, $\left.\mathrm{F}_{2.9}=5.01, \mathrm{p}=0.03\right)$ or $24 \mathrm{D}$, when no attacks occurred. In the chemical test, all treatments were similar $\left(\mathrm{F}_{2.15}=1.98, \mathrm{p}=0.17\right)$, ranging from the $24 \mathrm{~L}$ treatment $(1.11 \pm 1.42), 24 \mathrm{D}(4.50 \pm 5.68)$ and $12 \mathrm{~L} / 12 \mathrm{D}(4.33 \pm 2.30)$. The prey was accepted similarly by the experimental animals using both visual and chemical cues difference between the mean number of attacks in the visual and chemical tests was insignificant $\left(\mathrm{F}_{1.28}=0.17, \mathrm{p}=0.67\right)$.

Dark and light periods had similar numbers of fish stimulated, response times and numbers of attacks for visual and chemical tests (all $\mathrm{p}>0.05$ ). In the chemical tests, the difference between the mean initial reaction times to the presence of the stimulus was insignificant when the light and dark periods were compared $\left(\mathrm{F}_{1.16}=0.02, \mathrm{p}=0.88\right)$, but there was no homogeneity in the variances involving the number of attacks and the number of stimulated fish when the light and dark periods were compared.

\section{Ultrastructure of the retina}

Retinas of $N$. rossii have pigmented epithelial cells, neurons (e.g. photoreceptor cells) and cells that sustain these neurons (10 layers described for teleost fish). The retinal pigment epithelium has a single layer of cubic cells, each with a spherical nucleus, on the basal lamina (Bruch's membrane) that is rich in collagen fibers. Melanin granules or pigments are in the cytoplasm of the pigmented epithelial cells (Fig. 1). Mitochondria, endoplasmic reticulum and Golgi complexes are abundant and located mainly in the basal region of the cells and in the cytoplasmic membranes detached from the external segment of the photoreceptor cells (Fig. 1). The adjacent epithelial cells are united via junctional complexes (Fig. 2).

Rods in N. rossii are long cylindrical cells with inner and outer segments, are fragile and may be covered by melanin in the pigment layer and may be mixed with the outer segments of the cones (Figs 3 and 4). Rods have calical processes similar to those found in cones. The accessory outer segment of the rods and cones have the same origins, yet in the rod it extends directly inside the accessory outer segment and takes an eccentric route inside the limiting membrane. Ultrastructurally, the outer segment of the rods is similar to that of the cones; however, the double membranes are not continuous with the extracellular space (Fig. 4).

The cones in $N$. rossii are variable. They may be single (single inner segment) or double (two inner segments of the same type and size fused together), but both are elongated with two distinct segments. The inner segment is rich in mitochondria while the outer is formed by a stack of bimembranous disks or double-membraned sacs in the shape of disks or lamellae (Figs 5 and 6). The nuclei of the cones are located in the outer nuclear layer, together with the nuclei of the rods. A barrier of fine calical processes originates in the apical portion surrounding the distal region of the inner segments of the cones (Figs 6 and 7). The outer segments of the cones are surrounded by, but not in contact with, calical processes.

An accessory outer segment of the cone emerges from the region of the connecting cilium as a lateral process that runs along the outer segment (Fig. 6). The accessory outer segment contains an amorphous substance with a slightly granular matrix, but without biological membranes. Calical processes are not present. Müller cells have apical microvilli in the myoid region of the cones (Fig. 8). These regions of interaction among photoreceptors form the outer limiting membrane.

\section{Ultrastructure of the olfactory rosette}

A pair of olfactory organs have a variable shape, from oval to semi-spherical, in the olfactory chamber below the skin of the nostrils. The olfactory epithelium is arranged in two rows of parallel lamellae $(26 \pm 7.56)$, perpendicular to a central raphe formed by loose conjunctive tissue comprising elastic reticular fibres, collagen and blood and lymphatic capillaries. Epithelium comprises the sides of each lamella with regions having sensory and non-sensory characteristics. Epithelium with nonsensory characteristics is in the peripheral parts of the lamella and has many mucous cells. The epithelium with sensory characteristics forms a continuous layer resting on the basal mem- 

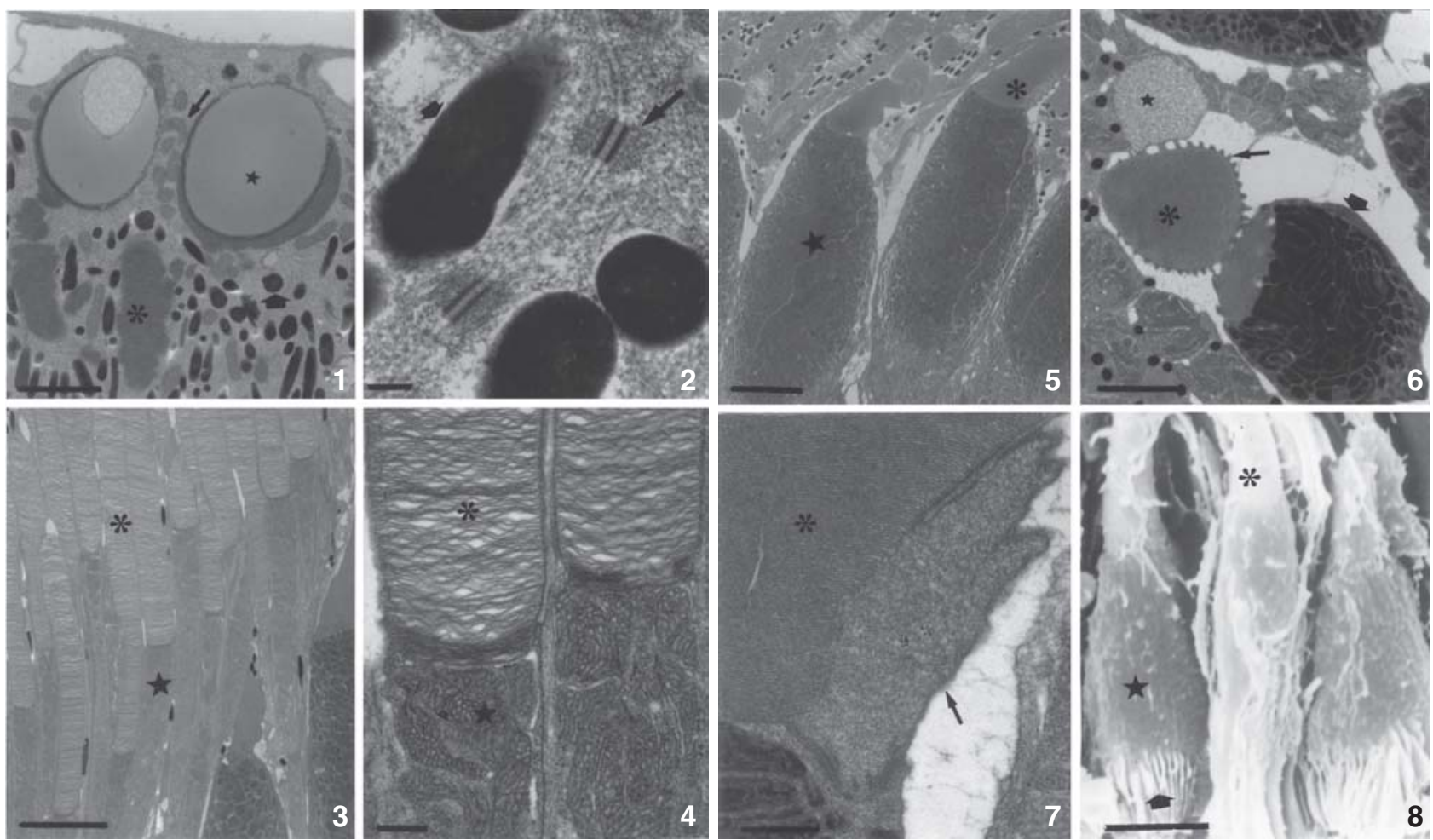

Figures 1-8. (1-4) Retinal pigment epithelium and rods of Notothenia rossii: (1) general aspect of the retinal pigment epithelium. Melanin pigment (thick arrow), detached membranes of the external segment of photoreceptors (asterisk), mitochondria (thin arrow) and lipid droplets (star) (scale: $2 \mu \mathrm{m}$ ); (2) detail of the retinal pigment epithelium. Desmossomes (thin arrow) and melanin pigment (thick arrow) (scale: $0.2 \mu \mathrm{m}$ ); (3) rods with inner segment (star) and outer segment (asterisk) (scale: $5 \mu \mathrm{m}$ ); (4) details of the rods. Inner segment rich in mitochondria (star) and the outer segment with bimembranous lamellae (asterisk) (scale: $1 \mu \mathrm{m}) ;(5-8)$ Cones of Notothenia rossii: (5) double cones with inner segment (star) and outer segment (asterisk) (scale: $5 \mu \mathrm{m}$ ); (6) single cones with inner segment (thick arrow), outer segment (asterisk), accessory outer segment (small star) and calycal process (thin arrow) (scale: $2 \mu \mathrm{m}$ ); (7) detail of the calycal process (arrow). Observe the cones with outer segment (asterisk) (scale: $0.5 \mu \mathrm{m}$ ); (8) cones with inner segment (star), outer segment (asterisk) and appendices of Müller cells (scale: $10 \mu \mathrm{m}$ ). Figures 1-7 = TEM, Figure $8=$ SEM.

brane and covers the central part of the olfactory lamellae (Figs 9-12). The olfactory epithelium comprises small spherical cells with a spherical nucleus that occupies most of the cell. They are located mainly in the intermediary and superficial region of the epithelium.

Sensory cells are bipolar neurons with long processes towards the surface that become cilia on the surface (Figs 11 and 12). They have granular endoplasmic reticulum and parallel well-developed Golgi complexes, neurotubules and mitochondria. Long axons originated from the basal regions of these neurones form the olfactory nerve.

Close to the sensory cells are the support cells, columnar in shape, with the nucleus located in the middle or apical region of the olfactory epithelium. Junction complexes and desmosomes are observed both between the cells of the basal region and between the cells of the apical region of the epithelium (Fig. 10). Desmosomes join support cells and sensory cells and support cells present microvilli on the surface. These microvilli project into the interior of the layer of mucous that covers the epithelium.

The non-sensory epithelium surface is irregular, with deep gaps and many mucous cells (Figs 13 and 14). Also, long superficial folds, and microvilli form a kind of labyrinth, and are generally associated with mucous cells (Fig. 13). Goblet cells with mucous secretion mostly occur in the free margins of the rosette. Goblet cells have a small basal region of cytoplasm with a nucleus, mitochondria, granular endoplasmic reticulum and a well-developed Golgi apparatus. Depending upon the phase of secretory activity, the appearance and the size of the goblet cells vary: when cells are larger mucous granules are nearer the surface (Fig. 14).

Mucous cells secrete neutral mucous as detected by the positive reaction to the PAS technique. Carboxylated and sulphated acid mucous, indicated by the positive reaction to Alcian 

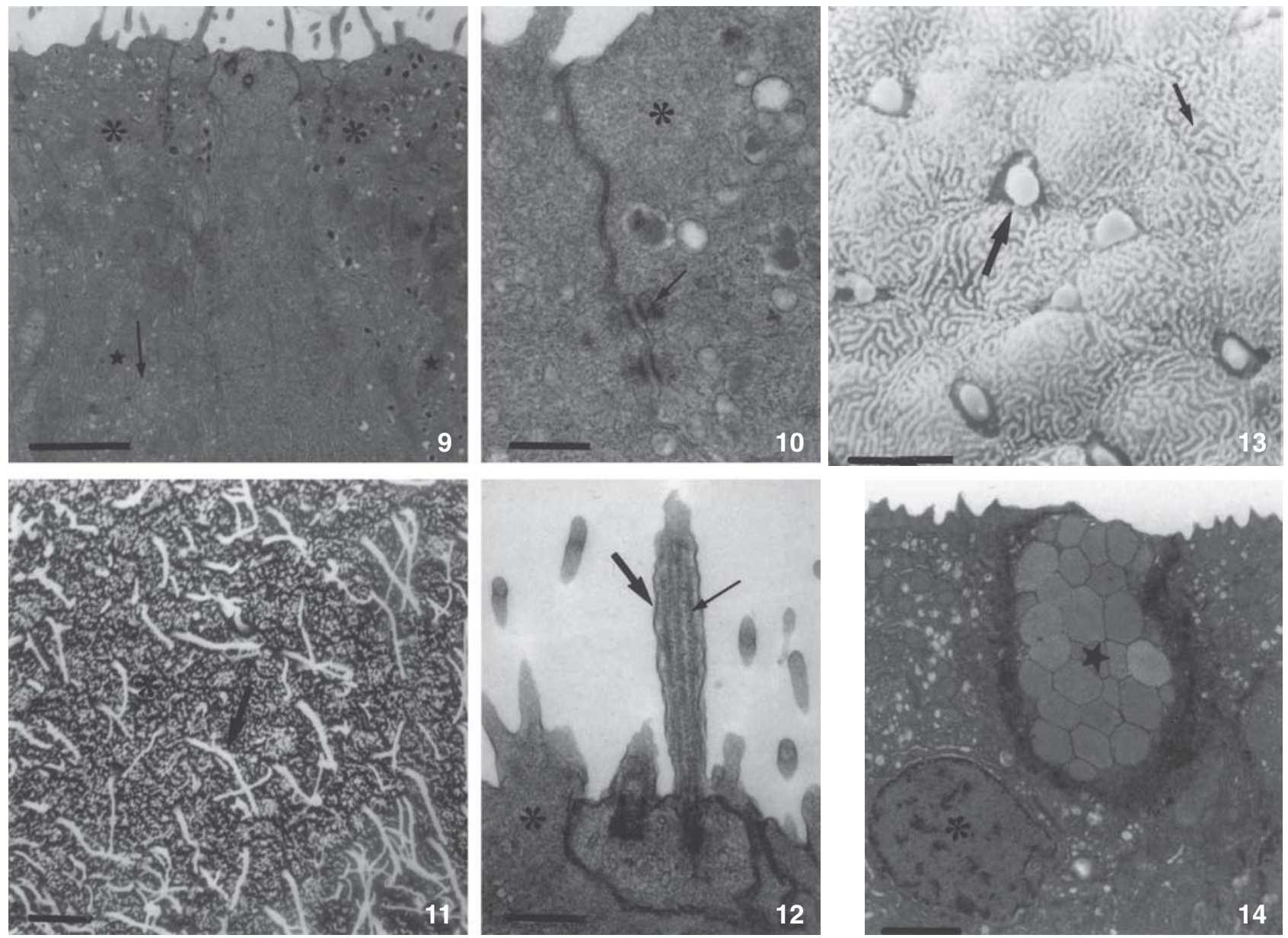

Figures 9-14. (9-12) Olfactory rosette of Notothenia rossii: (9) sensory epithelium with many mitochondria (star) and endoplasmic reticulum (arrow) (scale: $2 \mu \mathrm{m}$ ); (10) desmossomes (arrow) are between the cells of the epithelium (asterisk) (scale: $0.5 \mu \mathrm{m}$ ); (11) sensory cells (asterisk) emitting long processes toward the surface and are exteriorized in the form of cilia (arrow) (scale: $10 \mu \mathrm{m})$; (12) detail of the cilia (thick arrow). Sensory cells (asterisk) and the microtubules (thin arrow) (scale: $0.5 \mu \mathrm{m})$; (13-14) olfactory rosette of Notothenia rossii: (13) surface of the non-sensory epithelium with microridges (thin arrow) and mucous cells (thick arrow) (scale: $10 \mu \mathrm{m}$ ); (14) details of the mucous cells (star). Nucleus of the non-sensory cells (asterisk) (scale: $2 \mu \mathrm{m}$ ). Figures 9, 10, 12 and $14=$ TEM, Figure 11 and $13=$ SEM.

Blue $\mathrm{pH} 2.5$ and $\mathrm{pH}$ 1.0, respectively, were also found. The technique of Alcian Blue $\mathrm{pH}$ 2.5/PAS indicated that some cells possess both carboxylated acid mucous and neutral mucous.

\section{Ultrastructure of the lips}

The epidermis of both lips is broad with a variable number of cell layers, in which three layers stand out - basal, intermediate and surface (Fig. 15). The basal epithelial layer comprises cylindrical cells with oval to elongate nuclei, supported by a broad basal membrane (Figs 15 and 16). The intermediate region has elongated cells with the two extremities tapering off and forming a strongly united epithelium. Nearer the basal region, the nuclei are elongated and are more spherical closer to the apical region. All epithelium layers are strongly cohe- sive through a large quantity of desmosomes and hemidesmosomes, depending on the location (Fig. 17). Connective tissue is dense and made up of elastic and collagen fibers (Fig. 16). The apical layer is made up of squamous cells, with two to three layers, depending on the epithelial region. Viewed superficially, the cells are covered by short or punctiform microridges (Fig. 18).

Small numbers of mucous cells are on both lips, with the greatest concentration laterally. Mucous cells are globular and the nuclei are flat basolaterally. The mucous reacts positively to Alcian Blue pH 2.5 and to PAS and weakly to Alcian Blue $\mathrm{pH}$ 1.0 , indicating neutral carboxylated mucous and a small quantity of sulphated mucous. These cells stand out from the epithelial cells from the inner layer because they become larger

Revista Brasileira de Zoologia 25 (2): 254-262, June, 2008 

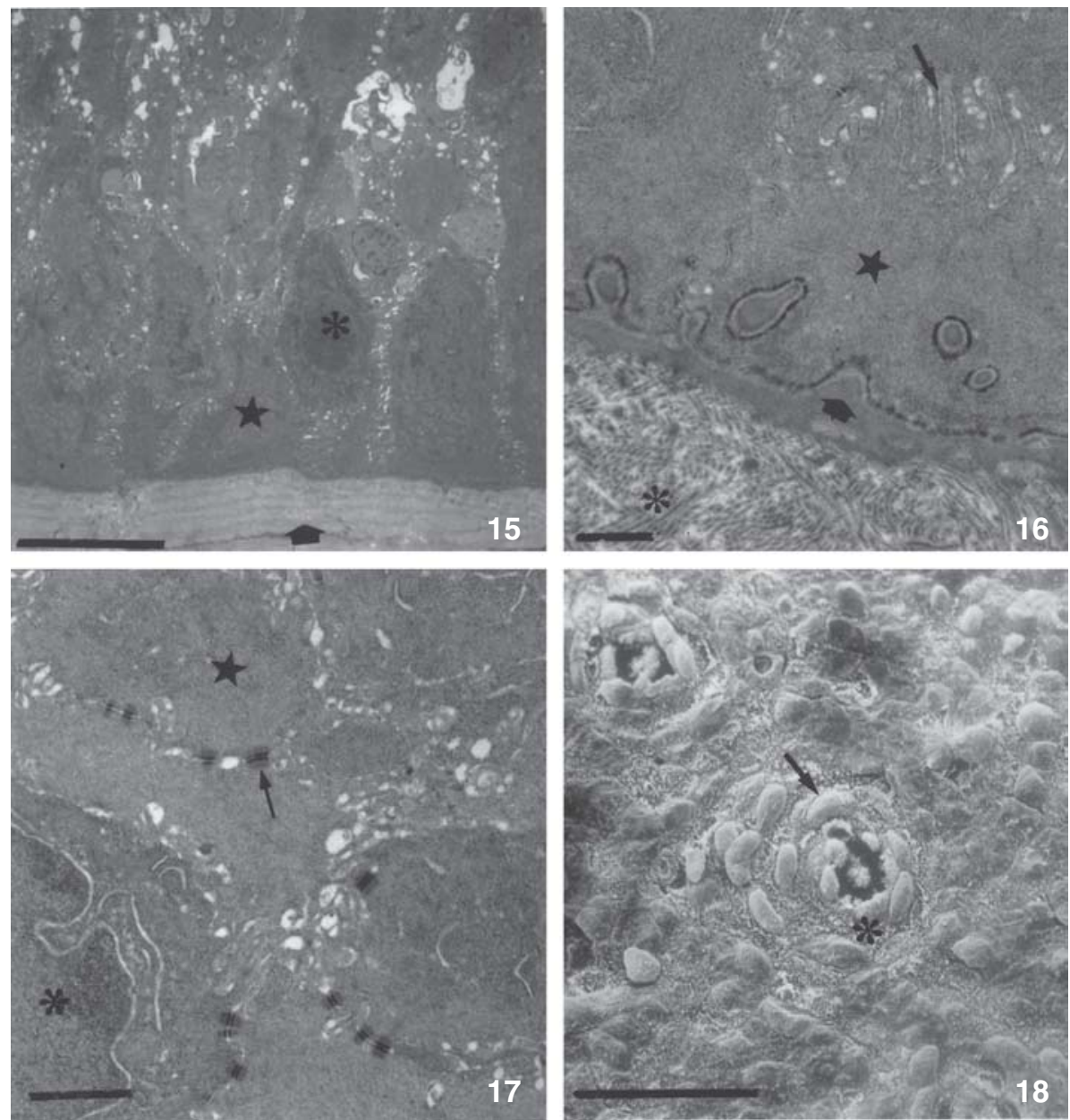

Figures 15-18. Lips of Notothenia rossii: (15) basal layer of the epithelium (star). Conjunctive tissue (arrow), nucleus of the epithelial cell (asterisk) (scale: $10 \mu \mathrm{m}) ;(16)$ detail of the basal layer of the epithelium (star). Basal membrane (thick arrow), conjunctive tissue rich of collagen fibers (asterisk), folding the membrane (thin arrow) (scale: $1 \mu \mathrm{m}$ ); (17) horizontal section showing the cells of the epithelium (star) strongly united through desmossomes (arrow). Nucleus of the epithelial cell (asterisk) (scale: $1 \mu \mathrm{m})$; (18) taste buds (asterisk) in the lips surrounded by concentric layers of epithelial cells (arrow) (scale: $0.1 \mu \mathrm{m}$ ). Figures 15-17 = TEM, Figure $18=$ SEM.

nearer the epithelial surface to release their content.

The upper lip has, in the central region, a slightly irregular surface with small protuberances and gaps. This surface becomes more irregular near the edges. Taste buds, of constant shape but variable size, are abundant in the central part of the lip (Figs 18-20). Taste buds have basal cells and support cells, with light nuclei in the middle. Sensory cells, with dark nuclei, are between support cells from which cytoplasmic processes extende towards the epithelial surface, where they become sensory (visible superficially, Fig. 20). Sensory cells are surrounded by undifferentiated epithelial cells covered by microridges. The taste buds of Notothenia rossii are elongated, between 100 and $130 \mu \mathrm{m}$ in height. Many folds of microvilli are found on the apical pole of the taste bud.

\section{DISCUSSION}

Notothenia rossii is an excellent biological model for the study of sensory systems in teleost fish due to its ecological plasticity, wide geographical distribution (Gon \& HeEmstra 1990) and life cycle with its changes in the diet, distribution and growth (Hureau 1970, Tarverdyieva 1972, Burchett 1983a). Morphological organization of sensory organs and their integration with fish response to sensory stimuli, are important for understanding the ecology and behavior of the species. More than one sensory system is probably always used by foraging fish to find food, hence it is difficult to generalize the relative importance of the roles of chemo and photoreception in the capture of prey. In aquatic systems smell and taste are carried

Revista Brasileira de Zoologia 25 (2): 254-262, June, 2008 


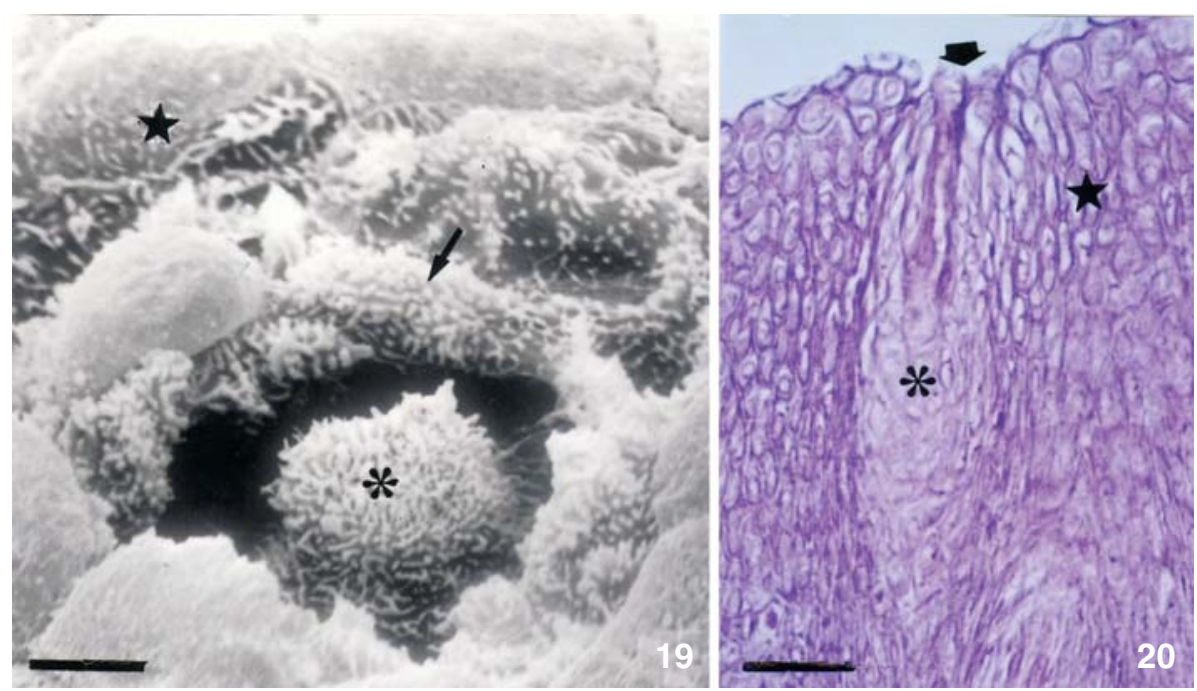

Figures 19-20. Lips of Notothenia rossii: (19) detail of one taste bud (asterisk) surrounded by concentric layers of epithelial cells (arrow). Epithelial cell (star) (scale: $10 \mu \mathrm{m}$ ); (20) detail of one taste bud (asterisk) with apex at the same level as the epithelium surface (arrow). Epithelial cell (star) (scale: $20 \mu \mathrm{m}$ ). Figure $19=$ SEM, Figure $20=$ LM, PAS.

in aqueous solutions. Smell is considered perception at a distance while taste requires contact of the element with the sensory structure (Hara 1971). Photoreception is also perception at a distance and depends on a complex retinal structure formed by photoreceptor cells, cones and rods.

When light was constant (photoperiod 24L), individuals were stimulated both chemically and visually, yet reactions were fewer and slower than during alternating periods of light and dark. In constant darkness with red light response to visual cues was least while response to chemical cues was similar to that of $12 \mathrm{~L} / 12 \mathrm{D}$. Apparently in nature, N. rossi feeds less during winter than during summer, even when prey are abundant (BURCHETT 1983a). Nototheniids are slow-swimming carnivores in general (EKAU 1991): for example, N. coriiceps Richardson, 1844 , is a sedentary species with limited mobility, at least at the end of spring and summer (BARRERA-Oro \& CASAUX 1990, Rios \& FANTA 1998).

Notothenia rossii feeds opportunistically on prey when it is more abundant and more easily caught (BURCHETT 1983b). Morphological analysis of the sensory structures may demonstrate this capacity. Cone and rod photoreceptors along with taste buds on the upper and lower lips, and an olfactory rosette with a sensory and a non-sensory epithelium rich in mucous are characteristics that help these fish to detect and select food.

Photoperiods and the stimuli (chemical or visual) had similar response intervals. However, the shortest reaction time to the visual or chemical stimulus occurred with light, mainly in $12 \mathrm{~L} / 12 \mathrm{D}$. Notothenia rossii reacts more readily to prey when stimulated visually. This may haven been due to the methodology of constant motion of the piece of fish used as a stimulus during the entire experiment. Prey should be sufficiently mobile to stimulate fish (Duarte \& Moreno 1981) and, in N. coriiceps, pursuit of $L$. nudifrons began immediately once it began to swim away (FANTA 1999). In this context, perhaps an improvement on the experiment would be to include live bait, such as fish, krill or amphipods.

Sensory organs of $N$. rossii are complex when compared to some other Antarctic fish such as Gobionotothen gibberifrons Lönnberg, 1905 or Ophthalmolycus amberensis Tomo, Marshoff \& Torno, 1977, but similar to those of $N$. coriiceps Richardson, 1844, Trematomus newnesi Boulenger, 1902, and Lepidonotothen nudifrons Lönnberg, 1905 (GrötZNER \& FANTA 1998, MEYER \& FANTA 1998, Fanta et al. 1999, 2001, Donatti \& Fanta 2001, 2002). With behavioral experiments and associated analysis of morphological structures permits a better understanding of feeding behaviors. Here we show that fish are more active foragers in light and under an alternating daylight regime.

\section{ACKNOWLEDGEMENTS}

We thank the CNPq (Projects 480.844/97-6 and 490.103/ 99-5) for finanical support and for the support to E. Fanta (300.831/93-5); CAPES for a PICDT-Doctorate Scholarship to L. Donatti; the logistical support by the Secretariat of the Interministerial Commission for Marine Resources (SECIRM) and the staff of the Brazilian Antarctic Station Comandante Ferraz (EACF).

\section{LITERATURE CITED}

Barrera-Oro, E.R. \& R.J. Casaux. 1990. Feeding selectivity in Notothenia neglecta from Potter Cove, South Shetland Islands, Antarctica. Antarctic Science 2 (3): 207-213. 
BurChetT, M.S. 1983a. Age and growth of the Antarctic fish Notohtenia rossii from South Georgia. British Antarctic Survey Bulletin 60: 45-61.

BurCheTt, M.S. 1983b. Food, feeding and behavior of Notothenia rossii marmorata nearshore at South Georgia. British Antarctic Survey Bulletin 61: 45-51.

Casaux, R.J.; A.S. Mazzota \& E.R. BarRera-Oro. 1990. Seasonal aspects of the biology and diet of nearshore nototheniid fish at Potter Cove, South Shetland Islands, Antarctica. Polar Biology 11: 63-72.

CCAMLR. 2007. Report of the Working Group on Ecosystem Monitoring and Management. In: Report of the XXVI Meeting of the Scientific Committee. Hobart, CCAMLR, 20p.

Clark, G. 1981. Staining procedures. Baltimore, Willians \& Wilkins, $4^{\text {th }}$ ed., $512 p$.

Culling, C.F.A.; R.T. Allison \& W.T. Barr. 1985. Cellular Pathology Technique. London, Butterworth, 642p.

DonatTi, L. \& E. Fanta. 1999. Morphology of the retina in the freswater fish Metynnis rooseveti Eigenmann (Characidae, Serrasalminae) and the effects of monochromatic red light. Revista Brasileira de Zoologia 16 (1): 151-173.

DONATTI, L. \& E. FANTA 2001. Ultrastructure of photosensory cells and pigment epithelium in the retina of the Antarctic fish Notothenia neglecta Nybelin (Nototheniidae). Antarctic Record 45 (3): 297-310.

DonatTI, L. \& E. FanTa. 2002. Influence of photo period on visual prey detection in the antarctic fish Notothenia neglecta Nybelin. Antarctic Science 14 (2): 146-150.

DONATTI, L. \& E. FANTA. 2007. Fine structure of the retinal pigment epithelium and cones of Antarctic fish Notothenia coriiceps Richardson in light and dark-conditions. Revista Brasileira de Zoologia 24 (1): 33-40.

Duarte, W.E. \& C.A. Moreno. 1981. The specialized diet of Harpagifer bispinis: Its effect on the diversity of Antarctic interdital amphipods. Hydrobiology 80: 241-250.

EAstman, J.T. 1988. Ocular morphology in Antarctic notothenioid fishes. Journal Morphology 196: 283-306.

EKAU, W. 1991. Morphological adaptations and mode of life in high antarctic fish, p. 23-29. In: G. Di Prisco; B. Maresca \& B. ТотА (Eds). Biology of Antarctic Fish. Berlin, SpringerVerlag, 292p.

FANTA, E. 1999. Laboratory test on feeding interactions of some Antarctic fish from Admiralty Bay (King George Island, South Shetlands). Polish Polar Research 20 (4): 335-346.

FantA, E. \& A.A. MeYer. 1998. Behavioural strategies for feeding of the Antarctic fishes Notothenia neglecta, Notothenia coriiceps, Trematomus bernachii, Pagothenia borchgrewinki, Lepidonotothen nudifrons and Pleuragrama antarctica (Pisces, Nototheniidae). Antarctic Record 42 (3): 227-243.

Fanta, E.; A.A. Meyer; S.R. Grötzner \& M.F. Luvizotto. 1994. Comparative study of the feeding strategy and activity patterns of two Antarctic fish Trematomus newnesi Boulenger,
1902 and Gobionotothen gibberifrons (Lönnberg, 1905) (Pisces, Nototheniidae) under different light conditions. Antarctic Record 38: 13-29.

Fanta, E.; L. Donatti \& S. Fraiberguer. 1999. Visual sufficiency in food and initiation of feeding behaviour in the antarctic fish trematomus newnesi Boulenger, 1902. Antarctic Record 43 (2): 221-236.

FantA, E.; F.S. Rios; A.A. Meyer \& S.R. Grötzner. 2001. Chemical and visual systems in feeding behaviour of the Antarctic fish Ophthalmolycus amberensis (Teleostei, Zoarcidae). Antarctic Record 38: 13-29.

Fischer, W. \& J.C. Hureau. 1985. FAO Species Identification Sheets for fishery purposes: Southernn Ocean. V.II. Rome, Food and Agriculture Organization of United Nations, 471p.

Gon, O. \& P. C. Heemstra. 1990. Fishes of the Southern Ocean. Grahamstown, J.L.B. Smith Institute of Ichthyology, 462p.

GrötZnER, S.R. \& E. FANTA. 1998. Comparative morphology of the retina of the Antarctic fish Gobionotohen gibberifrons (Lönnberg 1905), Trematomus newnesi Boulenger 1902, Lepidonotothen nudifrons (Lönnberg 1905) and Notothenia neglecta Nybelin 1951. Pesquisa Brasileira Antártica 3: 31-47.

Hara, T.J. 1971. Chemoreception, p. 79-120. In: W.S. Hoar \& D.J. Randall (Eds). Fish physiology. New York, Academic Press, vol. 5, 600p.

HARA, T.J. 1986. Role of olfaction in fish behaviour, p. 152-176. In: T.J. Pitcher (Ed.). The behaviour of teleost fishes. London, Croom Helm, 740p.

Hureau, J. C. 1970. Biologie comparée de quelques poissons antarctiques (Nototheniidae). Bulletin de I'Institut Oceanographique 68: 1-244.

Linkowski, T. B.; P. Presler. \& C. Zukowski. 1983. Food habits of nototheniid fishes (Nototheniidae) in Admiralty Bay (King George Island, South Shetland Islands). Polish Polar Research 4 (1-4): 79-95.

Luft, J.H. 1961. Improvements in epoxy resin embedding methods. The Journal of Biophysical and Biochemical Cytology 9: 409-414.

Macdonald, J.A. \& J.C. Montgomery. 1991. The sensory biology of notothenioid fish, p. 145-162. In: G. Di Prisco; B. MAResCA \& B. ТотА (Eds). Biology Antarctic fish. Berlin, Springer Verlag, 292p.

McKenna, J.E. \& S.B. Saila. 1991. Shifts in the Antarctic demersal fish community of South Georgia Island. Fisheries Research 12: 109-124.

Meyer, A.A.N. \& E. Fanta. 1998. Morphofuncional study of chemo sensorial structures of the Antarctic fish Trematomus newnesi Boulenger, 1902 used for food detection and selection of chemo sensorial structure of the of chemo. Pesquisa Brasileira Antártica 3: 49-63.

Meyer-Rochow, V.B. \& M.A. Klyne. 1982. Retinal organisation of the eyes of three nototheniid fishes from the Ross Sea (Antarctica). Gegenbaurs Morphologisdes Jahrbuch 128: 762-777. 
Montgomery, J.C. \& S. Coombs. 1992. Function and evolution of superficial neuromasts in an Antarctic Notothenioid fish. Brain Behavior and Evolution 44: 287-298.

Montgomery, J.C. \& J.A. Macdonald. 1987. Sensory turning of lateral line receptors in Antarctic fish to the movements of planktonic prey. Science 235: 195-196.

Policansky, D. 1994. History and atlas of the fishes of the Antarctic Ocean. Science 2: 1002-1004.

Reynolds, E.S. 1963. The use of lead citrate at high $\mathrm{pH}$ as an electron-opaque stain in electron microscopy. Journal of Cell Biology 17: 208-212.

Rios, F.S. \& E. FANTA. 1998. Morphology of gill rackers and their ecological function in the feeding on the Antarctic fish Notohenia neglecta Nybelin, 1951. Antarctic Record 42 (2): 131-150.

SKÓRA, K. \& J. SOSINSKI. 1983. Observations on the ichthyofauna distribution in the regions of the Scotia Sea and Antarctic Peninsula. Polish Polar Research 4 (1-4): 49-55.

TARgett, T.E. 1981. Trophic ecology and structure of coastal
Antarctic fish communities. Marine Ecology Progress Series 4: 243-263.

TARverdyieva, M.I. 1972. Daily food consumption and feeding pattern of the South Georgian cod (Notothenia rossii marmorata) and the Patagonian toothfish (Dissostichus eleginoides) in the South Georgia area. Journal of Ichthyology 12 (4): 684-692.

Tarverdyieva, M.I. \& I.A. Pinskaya. 1972. The feeding of fishes of the families Nototheniidae and Chaenichthyidae on the shelves of the Antarctic Peninsula and the South Shetlands. Journal of Ichthyology 20: 50-59.

Valentincic, T.B. \& J. CAPrio. 1994. Chemical and visual control of feeding and escape bahaviours in the channel catfish Ictalurus punctatus. Physiology \& Behavior 55: 845-855.

Watson, M.L. 1958. Staining of tissue sections for electron microscopy with heavy metals. The Journal of Biophysical and Biochemical Cytology 4 (4): 475-478.

ZAR, J.H. 1984. Biostatistical analysis. London, Prentice Hall, 929p.

Submitted: 13.XII.2007; Accepted: 12.VI.2008.

Editorial responsibility: Paulo de Tarso da Cunha Chaves

Revista Brasileira de Zoologia 25 (2): 254-262, June, 2008 